\title{
The Ingham Indian Collection
}

Since the discovery of America the western world has responded enthusiastically to the lore of the natives of the New World. Early Spanish accounts of the Indians of Mexico and South America were translated and widely read in Europe. With the English plantations a new series of reports dealing with the coastal North American tribes appeared. Works on all American natives continued to be written during later colonial times when Spaniards moved into northern Mexico and California and when the English temporarily took Florida and filled in the region east of the Appalachians. Indian literature in English received a new stimulus in the nineteenth century with the crossing of the mountains and the rapid extension of white influence into the Midwest and far IVest.

We are perhaps most familiar with the romanticized natives of fiction: the rhythmic Hiawatha, or the unreal but curiously convincing Indian of James Fenimore Cooper. Pocahontas is the prototype of innumerable Indian maidens who were romantic companions of white men. Writers of history played upon appealing Indian themes, as in the conquest narratives of Prescott and in Parkman's treatment of imperial clashes in the wilderness. These works, as many readers recognized, successfully combined the popular attractions of fiction with the solid dignity of historical fact. As a larger number of American settlers came into contact with Indians still other genres arose. Explorers, trappers, Indian fighters, and frontier settlers wrote "Personal Recollections" of their contacts with the Sioux or the Kiowas or the Blackfeet. A common type was the "captivity", a record of the days, months, or years spent as a prisoner in Indian hands. Another was the military narrative, a description of a particular battle or series of battles against the red men. Increasingly the scientific value of Indian description came to be recognized, and accounts of all kinds took on a sober anthropological tone. Yet much that was purely exotic appeared under the guise of ethnographic legitimacy. 
A repertory of such dimensions and such variety inevitably attracted literary collectors. A tradition of specialized purchasing of books on the American Indian extends back to the early Spaniards and continues to the present. In the United States several important private collections were begun in the nineteenth century, and it is with one of these, the Indian library of Harvey Ingham, that we are here concerned.

A generation ago there would have been no need to explain or identify Harvey Ingham to an Iowa audience, for he was one of the best known figures in the state. As editor of the Des Moines Register he projected his views daily in Iowa's most distinguished newspaper. His editorials were famous for their trenchant wit and level-headed sanity. His father, William $H$. Ingham, had moved to Iowa from New York State in 1855 and later himself contributed to Indian literature in a book entitled Ten Years on the Iowa Frontier. Born in 1858, Harvey Ingham graduated from the University of Iowa in 1880. He developed his interest in Indian literature while serving as editor of a weekly newspaper at Algona. After moving to Des Moines in 1902 he proceeded seriously to gather rare books of many kinds. His Indian collection was partly historical, for he always maintained a strong interest in the early life and history of Iowa. Partly it reflected his concern for the welfare of a minority group, a subject that received frequent editorial attention in the Register. Partly, also, it reflected his own friendships with Iowa Indians, who were so impressed with his persuasive eloquence that they sometimes invited him to speak at their powwows.

The Ingham Indian collection was acquired by the University in 1950, the year following Harvey Ingham's death, as a gift from his son, William $\mathbf{H}$. Ingham. Its approximately five hundred volumes are preserved among the Special Collections in the University Library. Suggestions have occasionally been made for enlarging or modernizing the holdings and for using them as a nucleus for an exhaustive collection on the Indians of Iowa and the Midwest under University auspices. But so far the Library's additional acquisitions in these fields have not been integrated with the Ingham material and the original collection remains intact.

Geographically the items of the collection range from New England to the west coast. Harvey Ingham clearly understood that the Indians of the Midwest could not be considered in isolation from those of other areas and that Indian history as a whole, however extensive, is an integral subject. His most concentrated attention nevertheless was devoted to the aspects of Indian history closest to his own region 
and experience. There is little specifically on the great Indian civilizations of Mexico and Peru, little on ancient man in the Americas, little on Indian archaeology. Certainly what attracted him most was the "classic" Indian of the period of white contact in the nineteenth century, the Indian of the pioneers.

The earliest authority on the native peoples of the central portion of North America, and perhaps the foremost of American students of the nineteenth-century Indian, was Henry Rowe Schoolcraft. As an Indian agent with headquarters in Sault Ste. Marie in 1822, Schoolcraft married a half-breed Ojibwa girl, and his ethnographic researches, beginning with the Ojibwa peoples, later encompassed in one way or another nearly all the native peoples of the country. The Ingham collection includes a particularly fine example of Schoolcraft's major work, Historical and Statistical Information Respecting ... the Indian Tribes of the United States, published in six volumes from 1851 to 1857. The work surveys Indian civilization broadly, with lengthy discussions of origins, mythology, history, language, "antiquities", "mental type", and many other subjects. Though long superseded, it was one of the most distinguished publications of its time on American native civilizations, and it gave a tremendous impetus to Indian studies.

Numerous successors appeared after Schoolcraft, and the Ingham collection includes a generous sampling of their writings. The most pretentious works were large single volumes or multi-volume sets in dignified formats and fine bindings. An example is The Indian Races of North and South America (1864) by Charles De Wolf Brownell, a comprehensive tome covering the native peoples of the hemisphere and an impressive example of American book manufacture. Others were less elaborate and the range of publication styles suggests the broad popularity of this kind of encyclopedic treatment, as if an effort were made to supply something at every price level. Almost without exception the contents of these books were unoriginal. Like modern textbooks, they drew heavily on one another. Occasionally, as if in recognition of sameness, an effort might be made to introduce something contemporary and new: a recently discovered site or tribe, an up-to-date description, a fresh account of some incident of strife. Brownell found a degree of originality in a timely report on the Sioux massacres in Minnesota, and then as later this was the most important part of his work.

The comprehensive or encyclopedic treatment reached its culmination in the Handbook of American Indians North of Mexico, by Frederick W. Hodge, issued in two volumes in 1907. In contrast to a work 
such as Brownell's, Hodge's Handbook reflects the full transition to scientific ethnography. Brownell's Indian Races was written for wealthy armchair travelers. Hodge's Handbook was written for scholars. Indeed scholars still depend on it, and in important ways it has not been replaced. The Ingham collection contains the original Smithsonian publication of 1907 .

The personal narratives of white relations with Indians still make dramatic reading. Many of them appear in the stilted language that readers expected, and with the wordy titles of another era. But they have an immediacy and an authenticity that places them among the most intriguing items of the collection. Some of the titles are formidable, for they run on and on, providing more and more detail, and emerging as title and summary and advertisement all at once. The title page of Colonel Richard Dodge's narrative of 1882 is like an eyecatching poster: Our Wild Indians: Thirty-three Years' Personal Experience among the Red Men of the Great West. A Popular Account of Adventures and Experiences on the Great Plains and in the Mountains of our Wide Frontier. The less subtle treatments were condensed and reissued as boys' books. The more dignified ones provided material for history or objective descriptions. But the theme of terror and the circus-poster appeal of this literature were almost invariably present. At times the titles became screaming invitations to vicarious thrills, and the texts played upon the savage horrors of Indian cruelty.

A large part of the terror literature concerned Indians of the Mississippi Valley and the plains-partly because these were areas of fierce resistance to white intrusion, partly because white intrusion took place here on an unprecedented scale, provoking frequent incidents of conflict. The "captivities" and battle accounts in the collection include numerous midwestern examples. The Spirit Lake Massacre of 1857 , the most renowned single Indian incident in the history of Iowa, receives attention in several writings, including a first edition of the history of the massacre by L. P. Lee.

The published literature on the American Indian is remarkable for its pictorial content, and one is struck again in reviewing a collection such as this by its significance as graphic presentation. The Indian was a colorful figure, and he could not be adequately portrayed by words alone. From the beginning Indian society attracted white observers proficient with pencil and brush, and every publication that sought to rise above mediocrity (as well as many that did not) included illustrations.

George Catlin (1786-1872) is of course the most celebrated name in that portion of American art history that relates to Indian life, and 
the Ingham collection has a number of works by and about him. A self-taught portrait painter, Catlin spent his summers from the 1830's on among the Indian peoples of the frontier, sketching and painting. He produced in all over a thousand portraits and scenes and made his living by exhibiting his collection in the cities of the United States and Europe. One of the most interesting of nineteenth-century travel books is Catlin's account of his tours in Europe, where he displayed paintings and panoramas and Indian artifacts and even living Indians to European audiences. Again in Catlin, though he was a serious and faithful artist, the themes of exoticism and showmanship appear.

The direct and indirect imitators of Catlin were legion, and his influence pervades the colorful book illustrations that nineteenth-century readers insisted upon. The histories and encyclopedic works of the latter part of the century were sometimes disguised biographies of Indians: Red Jacket, the Seneca War Chief; Mohongo, the Osage woman; Sharitarish, the Pawnee Chieftain. These were expectable figures in the publications of a hundred years ago. Each was presented in a colored portrait showing bright war paint or gay accoutrements or elaborate military garb. The pictorial tradition extended from this kind of decorative and lush (and sometimes extremely informative) representation to imaginative scenes of action in the captivities and narratives of terror. In the later writings the illustrative material occurs in the form of photographs, and these also, in the background detail and the miscellaneous paraphernalia of camp life, provide important historic data.

To a true aficionado an Indian collection is a wonderful thing, a source of unending pleasure. One needs only the briefest acquaintance with the Ingham Collection to know that Harvey Ingham responded affirmatively to the recorded lore and tradition of aboriginal America. Though the collection's value is now historical, we still may share a measure of his enthusiasm.

Some First Editions in the Ingham Collection:

Armstrong, Benjamin G. Early Life Among the Indians. Ashland, Wiscon$\sin , 1892$.

Beltrami, J. C. A Pilgrimage in Europe and America, Leading to the Discovery of the Sources of the Mississippi. London, 1828, 2 vols. [1st Eng. Ed.]

Blair, Emma Helen, ed. The Indian Tribes of the Upper Mississippi Valley and Region of the Great Lakes. Cleveland, 1911-1912. 2 vols.

Brady, Cyrus Townsend. Northwestern Fights and Fighters. New York, 1907. Busby, Allie B. Two Summers Among the Musquakies. Vinton, Iowa, 1886. Chittenden, Hiram M. and Alfred Talbot Richardson, ed. Life, Letters and 
Travels of Father Pierre-Jean De Smet, S.J., 1801-1873. New York, 1905. 4 vols.

Dunn, J[acob] P[iatt], Jr. Massacres of the Mountains; a History of the Indians of the Far West. New York, 1886.

Finerty, John Frederick. War-Path and Bivouac, or the Conquest of the Sioux. Chicago [1890].

Ford, Thomas. A History of Illinois. Chicago, 1854.

Fulton, Alexander R. The Red Men of Iowa. Des Moines, 1882.

Garland, Hamlin. The Book of the American Indian. Pictured by Frederic Remington. New York, 1923.

Goodwin, Cardinal [Leonidas]. The Trans-Mississippi West (1803-1853). New York, 1922.

Grinnell, George Bird. The Fighting Cheyennes. New York, 1915.

Hans, Frederic M. The Great Sioux Nation. Chicago [1907].

Horn, Hosea B. Horn's Overland Guide, from the U.S. Indian Sub-agency, Council Bluffs, on the Missouri River, to the City of Sacramento, in California. New York, 1852.

Inman, Henry and William F. Cody. The Great Salt Lake Trail. New York, 1898.

Keim, De B[enneville] R. Sheridan's Troopers on the Border: $a$ Winter Campaign on the Plains. Philadelphia, 1870.

Lee, L. P., ed. History of the Spirit Lake Massacre: 8th March, 1857, and of Miss Abigail Gardiner's Three Month Captivity Among the Indians. New Britain, Conn., 1857.

Mumey, Nolie. The Life of Jim Baker, 1818-1898. Denver, Colo., 1931.

Quaife, Milo Milton. Chicago and the Old Northwest, 1673-1835. Chicago, [1913].

Riggs, Stephen R. Mary and I. Forty Years with the Sioux. Chicago, [1880].

Schoolcraft, Henry R. Travels in the Central Portions of the Mississippi Valley. New York, 1825.

Schoolcraft, Henry R. Historical and Statistical Information, Respecting the History, Condition and Prospects of the Indians of the United States. Philadelphia, 1851-1857. 6 vols.

Tallent, Mrs. Annie D. The Black Hills; or the Last Hunting Ground of the Dakotahs. St. Louis, 1899.

Tatum, Lawrie. Our Red Brothers and the Peace Policy of President Ulysses S. Grant. Philadelphia, 1899.

Thwaites, Reuben Gold, ed. Early Western Travels, 1748-1846. Cleveland, 1904-1907. 32 vols.

Ware, Eugene F. The Indian Wars of 1864. Topeka, Kansas, 1911. 


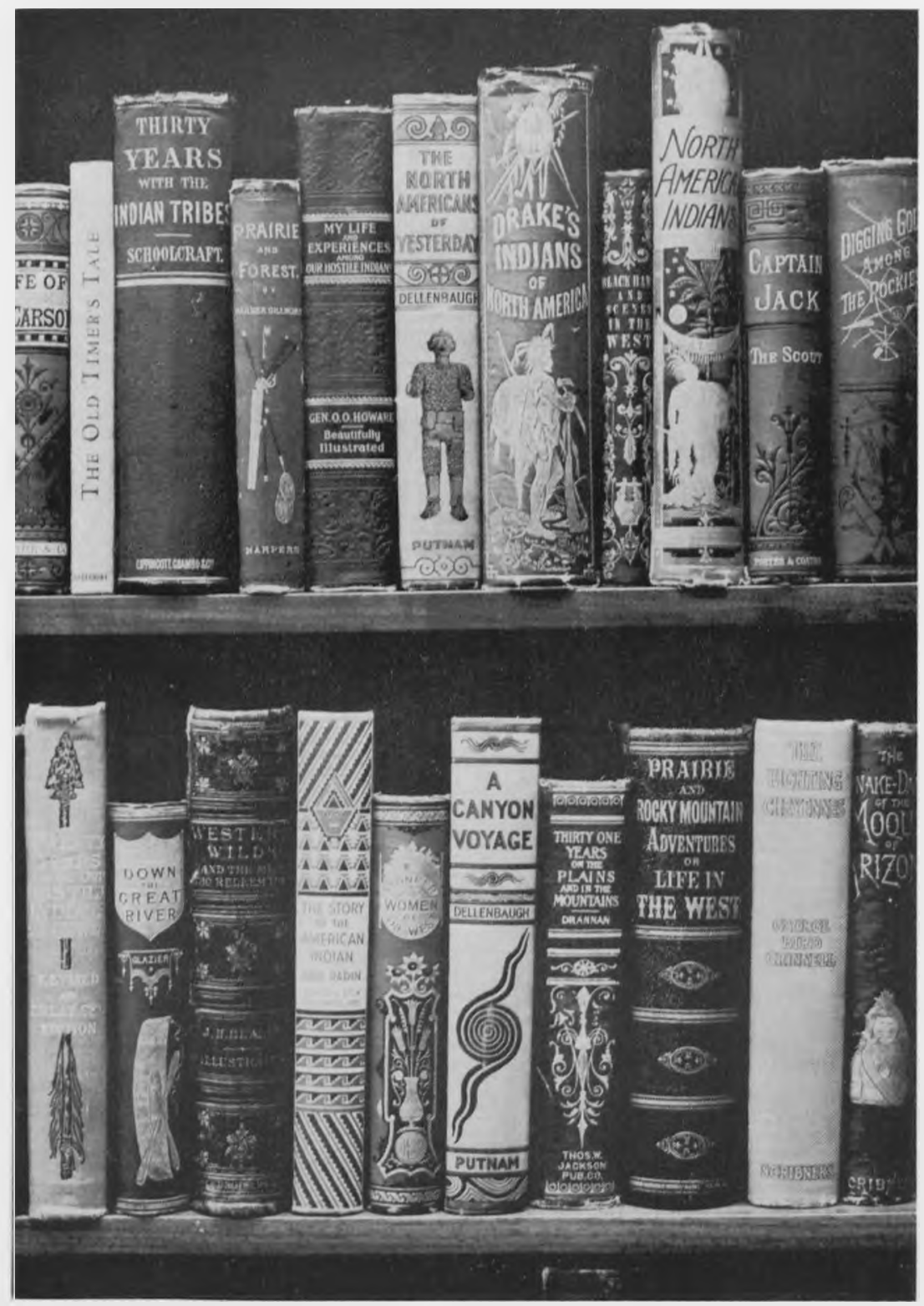

Books from the Ingham Inclian Collection. 


\section{INDIAN HORRORS}

OR.

\section{MASSACRES BY THE RED MEN.}

$111.1 \mathrm{Na}$

A THRILLING NARRATIYE OF BLOODY

IVARS WITH MERCILESS AND

REVENGEFUL SAVAGES,

IXCLUDING

A FULL ACCOUNT OF THE DARING DEEDS AND TRAGIC

DEATH OF THE WORI.D-RENOWNED CHIEF,

\section{SITTING BULL,}

WI'1H

STARTIING DESCRIPTIONS OF FANTASTIC GHOST DANCES ; MYSTERIOLS MEDICINE MEN; DESIERATE INDIAN BRAVIS ; SCAIPING OF HEI.PLESS SETTIERS; BCRXING THEIR HOMHS, ETC., ETC.

THE WHOLE

COMPRISING A FASCINATING HISTORY OF THE INDIANS FROM THE DISCOTERY OF AMER-

ICA TO THE PRESEN'T TIME; THEIR MANNERS, CUSTOMS, MODES OF WARFARE, LEGENDS, ETC.

BY HENRY DAVENPORT NORTHROP, D. D. Author of "Earth, Seaz, and Sky," ik., itc.

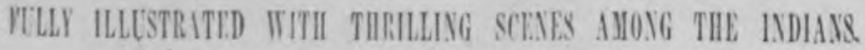

NATIONAI, PUBLISHING COMPANY,

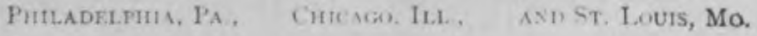

Title page from a volume in the Ingham Collection. 